Jurnal Indonesia Sosial Teknologi: p-ISSN: 2723 - 6609

e-ISSN : 2745-5254

Vol. 2, No. 9 September 2021

\title{
PERANCANGAN SISTEM INFORMASI INDIKATOR RAWAT INAP MENGGUNAKAN MICROSOFT VISUAL STUDIO DI RSIA LIMIJATI
}

\author{
Fajrina Aulya ${ }^{1}$, Irda Sari ${ }^{2}$ \\ Program Studi Informatika Rekam Medis, Politeknik Piksi Ganesha Bandung, \\ Indonesia $^{1,2}$ \\ Email: fajrinaaulya28@gmail.com ${ }^{1}$, irdasari13@gmail.com ${ }^{2}$
}

\begin{abstract}
Abstrak
Tugas seorang perekam medis di rumah sakit selain mengolah data pasien, juga melakukan pelaporan ketersediaan tempat tidur. Selama ini petugas rekam medis di RSIA Limijati masih menggunakan Microsoft Excel untuk melaporkan indikator rawat inap, maka terkadang petugas pelaporan kesulitan menghafal ramus. Tujuan dari penelitian ini adalah membuat perancangan sistem informasi indikator rawat inap sehingga memudahkan petugas dalam pelaporan harian maupun bulanan. Sistem Informasi Indikator Rawat menghasilkan pelaporan BOR, LOS, TOI, BTO, NDR, GDR, Form ketersediaan tempat tidur, Sensus Harian, laporan per-tanggal, per-kelas perawatan, per-bulan, dan laporan keseluruhan. Penelitian ini menggunakan metode deskriptif yang dirancang untuk mengolah data yang diperoleh dari penelitian Dengan adanya rancangan sistem ini, diharapkan dapat bermanfaat bagi institusi. Rancangan sistem ini masih banyak kekurangan dan kedepannya perlu dilakukan beberapa perbaikan.
\end{abstract}

Kata kunci: Perancangan Sistem Informasi; Pelaporan; Indikator Rawat Inap; Rekam Medis.

\section{Abstract}

The duties of medical recorder in a hospital except processing patient data's also reporting bed availability. So far medical recorder staff in RSIA Limijati still using Microsoft Excel for reporting hospitalization indicator, sometimes make the staff forgot the formula. The purpose of this research is made system information design hospitalization indicator, to facilitate the staff in daily and monthly reporting. System information hospitalization indicator produce report about BOR, LOS, TOI, BTO, NDR, GRD, form bed availability, daily census, daily report, report per-class treatment, monthly report, and all reporting. This research using a descriptive method designed to process data obtained from the research. With the design of this system, it is hoped that it will be useful for the institution. The design of this system still has many shortcomings and in the future some improvements need to be made.

Keywords: System Information Design; Reporting; Hospitalization Indicator; Medical Record. 


\section{Pendahuluan}

Rumah sakit menjadi salah satu institusi pelayanan kesehatan yang menyelenggarakan pelayanan kesehatan, pelayanan rawat inap, rawat jalan dan gawat darurat. Dalam pemberian layanan kesehatan diharapkan rumah sakit dapat memberikan pelayanan yang berkualitas. Secara umum dalam pemberian layanan ini, rumah sakit pun memberikan pelayanan terbaik dalam rekam medisnya (Giyana, 2012).

Rumah Sakit Publik adalah rumah sakit yang dikelola oleh Pemerintah, Pemerintah Daerah dan Badan Hukum yang bersifat nirlaba. Rumah Sakit Privat adalah rumah sakit yang dikelola oleh badan hukum dengan tujuan profit yang berbentuk perseroan terbatas atau persero (Permenkes No. 147 tahun 2010).

Kementrian kesehatan menyatakan bahwa pada beberapa negara maju, Badan Organisasi Akreditasi Rumah Sakit, menganggap bahwa rekam medis sangat penting dalam mengukur mutu pelayanan medis yang diberikan oleh rumah sakit beserta staf medisnya. Salah satu parameter keberhasilannya adalah menentukan mutu pelayanan kesehatan di rumah sakit adalah data atau informasi dari rekam medis yang baik dan lengkap. Indikatornya mutu rekam medis yang baik adalah kelengkapan isi, akurat, tepat waktu dan pemenuhan aspek persyaratan hukum.

Bentuk Rekam Medis dalam berupa manual yaitu tertulis lengkap dan jelas, dan dalam bentuk elektronik sesuai ketentuan. Rekam medis terdiri dari catatan-catatan data pasien yang dilakukan dalam pelayanan kesehatan. Catatan-catatan tersebut sangat penting untuk pelayanan bagi pasien karena dengan data yang lengkap dapat memberikan informasi dalam menentukan keputusan baik pengobatan, penanganan, tindakan medis dan lainnya. Dokter atau dokter gigi diwajibkan membuat rekam medis sesuai aturan yang berlaku (Lestari, Tania, \& Rahmi, 2011).

Tujuan dari rekam medis adalah sebagai penunjang tercapainya tertib administrasi dalam rangka upaya peningkatan pelayanan kesehatan. Tanpa didukung sistem pengelolaan rekam medis yang baik dan benar, maka tertib administrasi di tempat pelayanan kesehatan akan sulit berhasil seperti yang diharapkan (Perdana, Negara, \& Irwansyah, 2016).

Diperlukan sebuah metode yang lebih akurat dalam menggambarkan efisi-ensi penggunaan tempat tidur di rumah sakit. Oleh karena itu dibutuhkan kriteria / indikator untuk menentukan apakah tem-pat tidur yang tersedia telah berdaya guna atau berhasil guna. Indikator yang digunakan untuk memantau efisiensi penggunaan tempat tidur ini terdiri dari 4 parameter, antara lain : BOR (Bed Occupation Rate), BTO (Bed Turn Over), LOS (Length Of Stay), dan TOI (Turn Over Interval).

Dalam mencatat riwayat dan mengarsipkan data melalui rekam medis kesehatan menjadi hal penting dalam dunia medis. Dengan adanya data pada rekam medis dengan mudah pasien akan mengetahui acuan pemerikasaan kesehatannya, selain itu pencatatan ini digunakan sebagai bukti mengenai diagnosa pasien terkait penyakit yang dideritanya. Sedangkan bagi dokter, paramedis, dan pihak rumah sakit rekam medis ini digunakan agar bisa memperoleh data akurat karena segala informasi yang didapat dari pasien tercatat dalam rekam medis (Susanto \& Sukadi, 2011). 
Menurut Peraturan Menteri Kesehatan Nomor 269/MENKES/PER/III/2008, syarat mutu untuk rekam medis adalah adanya kelengkapan data dari isi rekam medis, hari dan tanggal (waktu) serta pemenuhan persyaratan spek hukum. Ada juga menurut SPM (Standar Pelayanan Minimal) rumah sakit menerangkan bahwa ada empat indikator sasaran mutu dimana salah satunya adalah ketepatan waktu penyediaan catatan rekam medis (Winati \& Supriyanto, 2013).

Di era reformasi ini, rumah sakit harus bisa meningkatkan kinerja dan daya saing yang tinggi sebagai salah satu sarana yang banyak dijumpai orang sakit. Rumah sakit pun dituntut harus bisa merumuskan kebijakan yang tepat apalagi untuk manajemennya. Dalam hal ini sistem manajemen informasi rumah sakit adalah sebuah sistem komputer yang dapat memproses dengan baik dan mengintegrasikan data kesehatan dalam bentuk jaringan koordinasi yang baik adanya prosedur administrasi yang dapat mengolah data dengan cepat dan pelaporan yang akurat. Adanya pembanguan sistem informasi berbasis komputer di rumah sakit akan menghasilkan rumah sakit digital yang terlihat lebih efisien dalam mengolah data (Handiwidjojo, 2015).

Saat ini pengembangan sistem informasi rekam medis banyak digunakan untuk jadi sarana pendukung adanya data informasi sebagai keterlaksanaannya pelayanan informasi bagia manajemen dan untuk pengembangan jaringan informasi dan data kesehatan. Semakin canggihnya dunia teknologi dalam mengolah data rumah sakit, manajemen informasi rumah sakit dapat berguna dalam proses untuk mengambil diagnosa pasien atau pengambilan keputusan medis. Dengan adanya rekam medis eketronik yang berbasis web serta berlangsung dengan online menggunakan komputer atau secara elektronik status pelayanan kesehatan yang diperoleh dapat tersimpan dengan amam dan menjadi arsip rumah sakit yang tersusun dengan rapuh dan penggunaan rekam yang sah. Apalagi saat ini perangkat elektronik dapat kita temui dalam kehidupan seharihari dengan mudah (Putra, 2015).

Manusia saat ini, tidak dapat telepas dari adanya teknologi yang berperan penting dalam kehidupan. Perkembangan teknologi pun sudah menjadi bidang yang cukup maju dan berkembang dengan baik. Tentu saja hal ini sangat membantu dan bisa mempermudah penyelesaian pekerjaan. Hal ini selaras dengan adanya kebutuhan administrasi digital di rumah sakit. Sudah banyak rumah sakit yang mengandalkan sistem manual dalam menyimpan data pasien ataupun hal lainnya. Namun saat ini sudah banyak rumah sakit yang mengandalkan kemajuan teknologi untuk membantu mempermudah dalam memanajemen data yang ada di rumah sakit yang biasa disebut rekam medis. Rekam medis ini memiliki perasan dalam proses administrasi laboratorium dari pasien sehingga adminintrasi nya harus bisa lebih teratur lagi. Harapannya dengan adanya pengarsipan semua data dapat membantu pelayanan untuk pasien (Sudarmilah, Supardi, \& Muliawan, 2017).

Sistem adalah sekumpulan unsur yang berhubungan antara satu dengan yang lainnya sedemikian rupa berproses mencapai tujuan tertentu, atau suatu tatanan dimana terjadi suatu kesatuan dari berbagai unsur yang saling berkaitan secara teratur menuju pencapaian unsur dalam batas lingkungan tertentu (Rustiyanto, 2010). 
Secara garis besar sistem informasi rekam medis memungkinkan pengguna dapat melakukan pengisisan, penyimpanan, memanggil ulang, mentransmisikan dan memanipulasi/mengolah data pasien secara spesifik baik ,perindividu atau kelompok, termasuk data klinis, administrasi dan demografi, sehingga dapat mengurangi pembiayaan operasional rumah sakit (Rustiyanto, 2010).

Biasanya data rekam medis banyak digunakan secara tertulis, kebiasaan ini membuat data mudah hilang, terbakar, rusak karna api dan jika hilang tidak ada arsip penggantinya. Ditengah kemajuan teknologi informasi dan komunikasi, segala bentuk informasi dapat diperoleh dengan cepat dan akurat. Saat ini informasi menjadi kebutuhan dasar seseorang untuk mendapatkan keperluan majemen dan pengambilan keputusan dengan jelas. Rumah sakit yang menjadi tempat untuk memberikan sumber informasi terkait riwayat pasiennya tentu harus didampingi dengan pengolahan data yang benar dan akurat.

Adanya perkembangan teknologi yang semakin pesat dan canggih sehingga perubahannya dari waktu ke waktu sangat signifikan. Hal ini terlihat jelas karena sebelum adanya perkembangan teknologi semua hal dilakukan secara sederhana, manual dan konvensional sehingga sangat diharapkan untuk saat ini segala bentuk administrasi bisa terlaksana secara online atau tersusun secara rinci dan jelas melalui aplikasi yang dapat merekap semua data termasuk dalam hal ini menyangkut dalam upaya pengelolaan rumah sakit yang tercatat dalam rekam medis. Menurut penelitian (Kaban 2012), kemajuan teknologi dan informasi memberikan banyak keuntungan seperti penyimpanan data, pengiriman data, pengaksesan data, dan pengelolaan informasi yang semakin cepat. Sehingga dengan adanya kemajuan teknologi ini menjadi sumber daya yang sangat diperlukan dan penting untuk bisa dikelola dengan baik. Baik buruknya suatu perusahaan atau instansi pun tergantungbagaimana mereka mengolah dan mengarsipkan administrasinya.

Sejalan dengan perkembangan teknologi maka diperlukan pengolah data yang lebih efektif dan efisien agar dapat mengurangi human error yang dapat terjadi akibat sistem yang masih dijalankan dengan manual. Sehingga alat pengolah data memegang peranan yang sangat penting untuk dapat menghasilkan data yang akurat (Priyadi \& Lestari, 2018).

Prosedur yang dilakukan saat pasien tiba di rumah sakit adalah dilakukannya pengelolaan rekam medis. Pedoman atau petunjuk nya dimuali saat diterimanya pasien ditempat penerimaan pasien setelah itu dilakukan pencatatan data medis pada pasien selama pasien berada di rumah sakit sampai penangan medis pada pasien seperti pengeluaran berkas dari permintaan dan peminjman untuk pasien yang mau berobat jalan, pengambilan obat atau hal lainnya. Apabila proses rekam medis tidak berjalan dengan cepat ditangani maka akam memberikan dampak yang buruk pada pelayanan di rumah sakit tersebut. Selain itu kehilangan status riwayat pasien membuat pihak rumah sakit akan kesulitan dalam melakukan tindak lanjut dalam mengobati pasien. Berdasarkan hasil penelitian (Tanjung \& Sukrianto 2017) sudah melakukan usaha untuk mendapatkan solusi 
yang terjadi di Rumah Sakit Jiwa Tampan dengan adanya aplikasi untuk mengolah data rekam medis.

Mengenai data pribadi pasien yang sangat diperlukan oleh dokter dan pegawai rumah sakit lainnya, perlu adanya administrasi khusus yang tercatat dalam rekam medis. Untuk dapat mengarsipkan dengan baik, membuat cadangan informasi, data yang direkap secara sistematis dan teliti serta didokumenkan secara online akan lebih menambah keefektifan rekam medis pasien. Penyimpanan berkas rekam medis secara konvensional menggunakan map atau selembaran kertas dengan si data riwayat pasien memiliki banyak kekurangan karena harus memiliki menyimpanan yang luas dan aman, jika data diperlukan maka harus mencari arsip satu persatu dengan waktu yang lama untuk mencarinya, dan resiko hilang lebih besar. Sedangkan jika diarsipkan secara online dalam komputer atau kedalam sebuah aplikasi yang menunjang dengan baik, informasi rekam medis akan lebih aman, tersusun rapih dan jika diperlukan kita akan lebih mudah untuk menemukannya.

Dalam perencanaannya, rekam medis secara online masih menjadi perdebatan yang masih diragukan baik dan buruknya. Meskipun sudah jelas mengenai kakurangan dan kelebihannya namun inonasi pencapaian untuk mendapatkan aplikasi yang sesuai masih sulit dibuatkan. Dalam rekam medis biasanya memuat identitas pasien secara lengkap. Di Indonesia penggunaan rekam medis online belum berkembang pesat sesuai dengan yang diinginkan, oleh karena itu perlu adanya pembaharuan dan pengembangan khusus terkait aplikasi yang sesuai untuk digukanakan dalam perencanaan aplikasi rekam medis (Handiwidjojo, 2017).

Akhirnya kunci yang paling menentukan apakah RME akan diadopsi atau tidak terletak pada ada tidaknya kebutuhan, bukan teknologinya, baik menurut dokter maupun manajemen rumah sakit. Selama dokter merasa mampu memberikan pelayanan yang terbaik seperti saat ini, maka proses adopsi akan berjalan lambat, demikian pula jika pihak manajemen tidak melihat sisi positif kebutuhan informasi di tingkat manajemen maka RME hanya akan menjadi wacana. Semoga tulisan ini dapat menumbuhkan kesadaran bagi pemerintah pembuat regulasi, pengambil kebijakan di rumah sakit maupun pasien untuk segera menyadari arti penting dan manfaat RME, agar migrasi dari rekam medis manual ke rekam medis elektronik (RME) tidak berjalan di tempat (Handiwidjojo, 2017).

Tantangan yang harus dihadapi dalam pembuatan aplikasi rekam medis secara komputerisasi yaitu penjaminan data yang tetap harus tersimpan dengan baik secara komputerisasi harus memiliki unsur kerahasiaan dan keamanan karena semua data pada rumah sakit bersifat privasi. Selain itu ketersediaan dana untuk menyediakan fasilitas secara komputerisasi. Hal ini karena aspek finansial dari tiap rumah sakit yang belum bisa memenuhi standar. Tujuan dari penelitian ini adalah membuat perancangan sistem informasi indikator rawat inap sehingga memudahkan petugas dalam pelaporan harian maupun bulanan. Sistem Informasi Indikator Rawat menghasilkan pelaporan BOR, LOS, TOI, BTO, NDR, GDR, Form ketersediaan tempat tidur, Sensus Harian, laporan pertanggal, per-kelas perawatan, per-bulan, dan laporan keseluruhan. Jika melihat manfaat yang bisa diambil dari adanya rekam medis secara komputerisasi ini yaitu secara 
operasional kita sudah bisa mendapatkan keakurasian data, kecepatan penyelesaian, keefesiensian dalam proses input data dan memudahkan kita dalam melakukan pelaporan.

\section{Metode Penelitian}

Penelitian ini telah dilaksanakan di Rumah Sakit Limijati yang berada di Jalan LLRE Martadinata St. No. 39 Citarum, Bandung Wetan Kota Bandung. Metodologi penelitian yang digunakan adalah pendekatan deskriptif yang dirancang untuk mengolah data yang diperoleh dari penelitian. Data diambil dari berbagai aspek dan kebutuhan, maka dapat ditarik kesimpulan sistem informasi ini dirancang untuk memenuhi kebutuhan pada rumah sakit. Sedangkan jenis pengolahan data menggunakan metode penelitian kualitatif. Data kualitatif adalah data yang berkaitan dengan kategori, karakteristik atau variabel. Penelitian secara kualitatif menjadi salah satu metode penelitian yang dilakukan dengan tujuan utama untuk membuat gambaran deskripsi tentang suatu keadaan secara obyektif.

Sumber data yang diambil berdasarkan hasil pada rekapan database komputerisasi yang diinput menggunakan aplikasi sistem informasi indikator rawat inap meliputi data nama, ruangan, jam masuk dan keluar, lama perawatan, diagnosa dan keadaannya. Sedangkan yang menjadi subjek adalah pasien yang terdapat dalam database online secara keseluruhan dan terpantau melalui rekam medis ini. Pengumpulan data diperoleh juga dari pihak rumah sakit berdasarkan data yang berkaitan dan mendukung. Proses pengumpulan data dilakukan dengan mengkordinir seluruh data yang masuk kedalam catatan rekam medis untuk menggali secara lengkap dan jelas terhadap variabel-variabel penelitian guna memenuhi kebutuhan informasi yang diinginkan peneliti yang sesuai dengan tujuan penelitian.

\section{Hasil dan Pembahasan}

\section{Tampilan Tahapan Pembuatan Konsep Aplikasi Sistem Informasi Indikator Rawat Inap Menggunakan Microsoft Visual Studio 2010 Di RSIA Limijati}

Pembuatan aplikasi sistem informasi indikator rawat inap menggunakan microsoft visual studio 2010 di RSIA Limijati diawali dengan adanya keterbatasan dalam mengolah data rekam medis yang ada di RSIA Limijati yang masih melakukan perekapan data secara manual. Hal ini di sebabkan karena rumah sakit belum mempunyai fasilitas yang mampu mengolah data pelaporan dengan cepat dan akurat, sehingga perlu adanya inovasi untuk menangani masalah ini. Analisis terhadap kebutuhan-kebutuhan rumah sakit dilakukan agar pembaharuan yang dilakukan bisa tepat sasaran. Berdasarlam beberapa analisis yang dilakukan mengenai permasalahan yang ada di RSIA Limijati dengan adanya kemajuan teknologi dalam pembuatan aplikasi sistem informasi indikator rawat inap menggunakan microsoft visual studio 2010.

Setelah menganalisis dan membuat rancangan aplikasi yang akan dibuat, peneliti membuat flowmap. Pembuatan flowmap digunakan sebagai gambaran dan deskripsi dari komponen aplikasi tersebut. 
Fajrina Aulya ${ }^{1}$, Irda Sari ${ }^{2}$

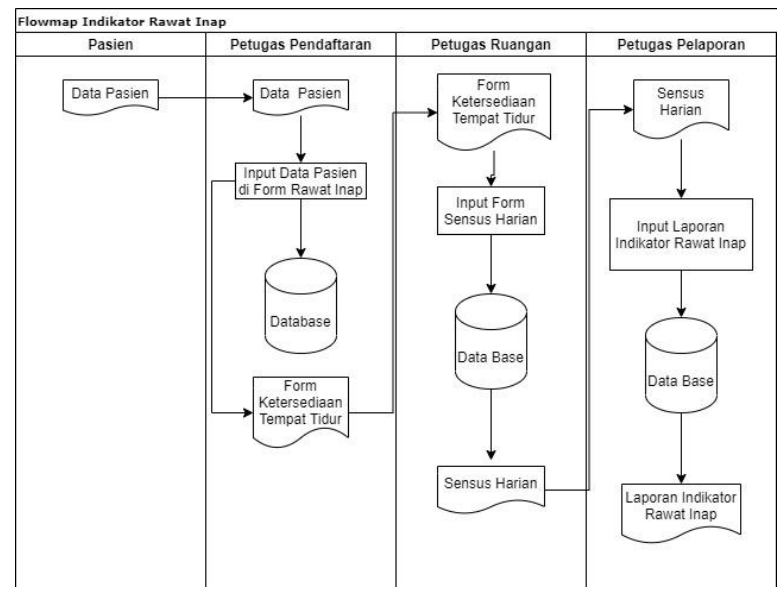

Gambar 1. Flowmap Indikator Rawat Inap

Mekanisme pelaporan indikator rawat inap dimulai dari pasien datang ke rumah sakit, lalu ke petugas pendaftaran. Data pasien di input oleh petugas pendaftaran ke dalam form rawat inap. Setelah itu data pasien masuk ke dalam database. Petugas pendaftaran melihat ketersediaan tempat tidur yang selalu di update setiap saat dalam form ketersediaan tempat tidur. Petugas ruangan input data pasien ke form ketersediaan tempat tidur agar jumlah tempat tidur yang tersedia selalu ter-update. Setelah itu seluruh data pasien, data ruangan, dan data ketersediaan tempat tidur akan di input ke dalam form sensus harian oleh petugas ruangan. Sensus harian di olah dan di laporkan oleh petugas pelaporan.

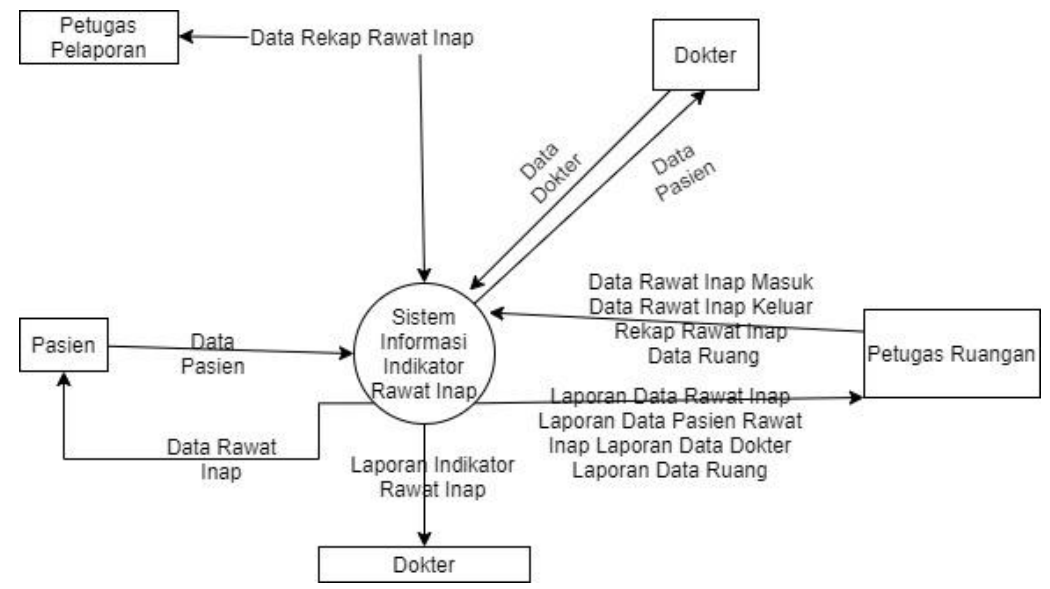

Gambar 2. Diagram Konteks 


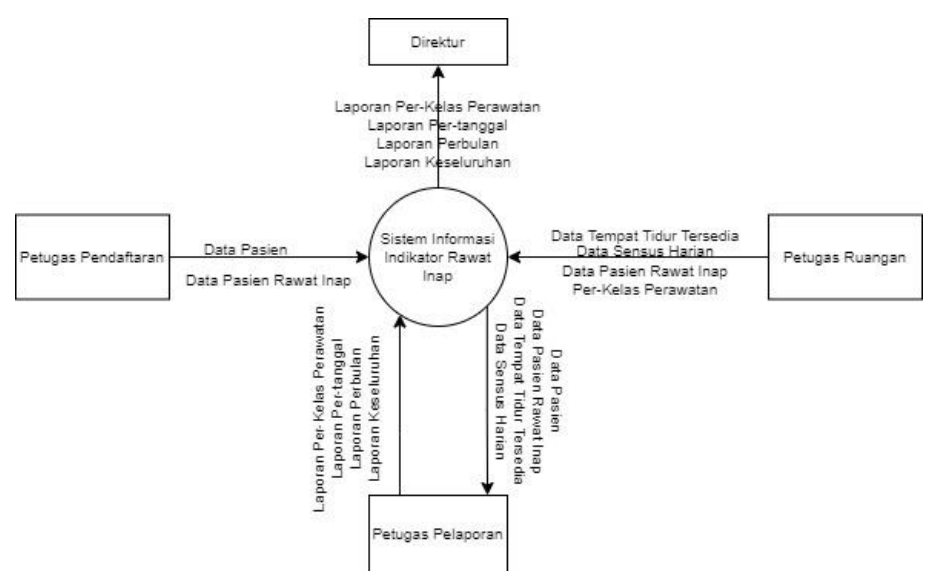

Gambar 3. DFD Level 0

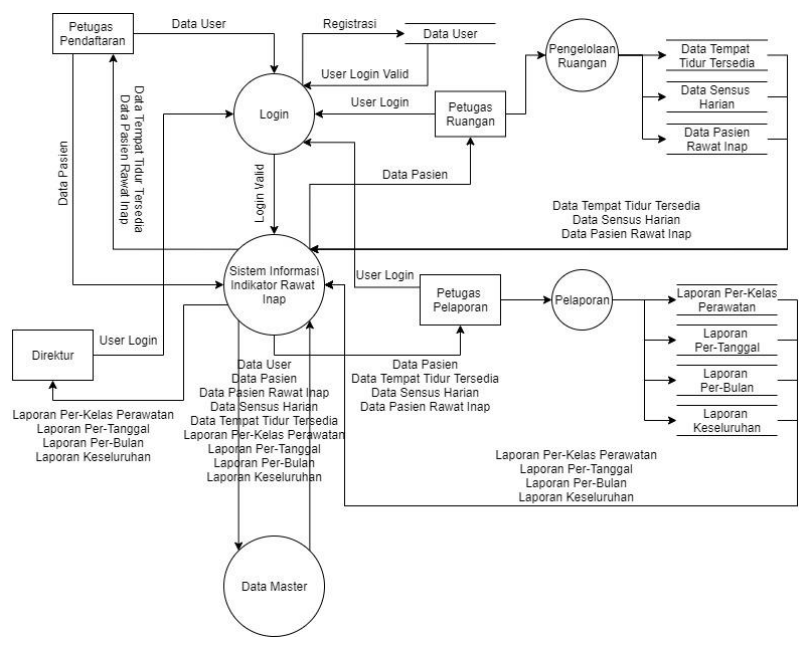

Gambar 4. DFD Level 1

\section{Tampilan Aplikasi Sistem Informasi Indikator Rawat Inap Menggunakan Microsoft Visual Studio 2010 Di RSIA Limijati}

Berdasarkan hasil penelitian maka perlu adanya suatu inovasi baru dalam proses pengolahan rekam medis. Rekam medis menjadi salah satu hal penting untuk mengetahui riwayat data pasien yang dibutuhkan oleh tenaga medis. Dengan adanya proses pengolahan rekam medis berbasis komputerisasi akan lebih mempermudah pendataan karena semua informasi terekap secara manual. Proses perekapan dan pengisian data yang dilakukan melalui Aplikasi Sistem Informasi Indikator Rawat Inap Rumah Sakit Limijati didesain dengan detail informasi yang akan diinput dengan mudah dan proses yang cepat. Ada beberapa langkah registrasi dan menu yang ada pada Aplikasi Sistem Informasi Indikator Rawat Inap yaitu : 
Fajrina Aulya ${ }^{1}$, Irda Sari ${ }^{2}$

\section{Form Registrasi}

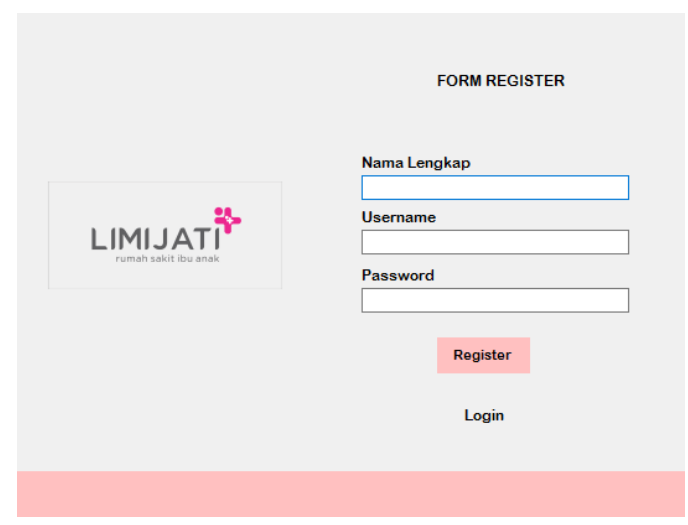

\section{Gambar 5. Form Registrasi}

Bagian form registrasi menjadi bagian paling utama untuk bisa masuk ke aplikasi tersebut. Pembuatan akun pada aplikasi menjadi syarat untuk bisa mengoprasikan aplikasi. Ada beberapa hal yang perlu diisi pada form registrasi ini sebagai tanda bahwa ada akun yang akan mengelola data pada aplikasi ini. Cara membuat akunnya cukup dengan mengisi nama lengkap, username dan password. Pembuatan akun pada form registrasi selanjutnya akan digunakan untuk bisa masuk pada aplikasi dan menekan tombol login.

\section{Form Login}

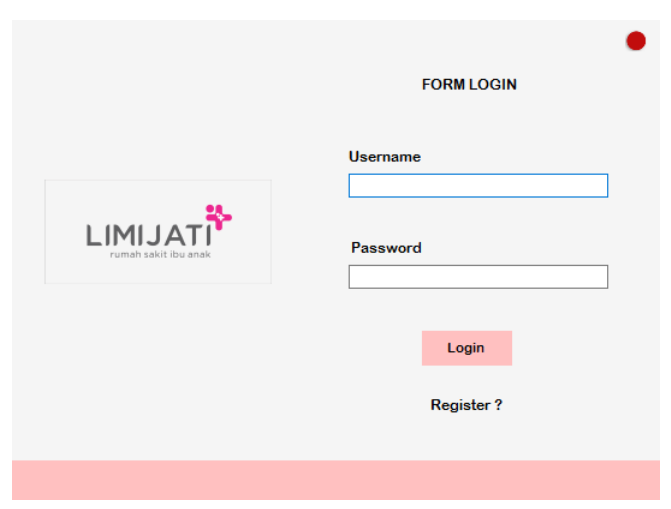

\section{Gambar 6. Form Login}

Form login dan register tentu saja berbeda. Jika form register untuk membuat akun, maka pada menu login ini tinggal memasukkan username dan password yang telah dibuat pada form registrasi sebelumnya. Setelah masuk ke form login ini, operator bisa langsung mengoperasikan menu utama/ dashboard dan form-form lain pada system informasi tersebut. 
3. Dashboard/Menu Utama

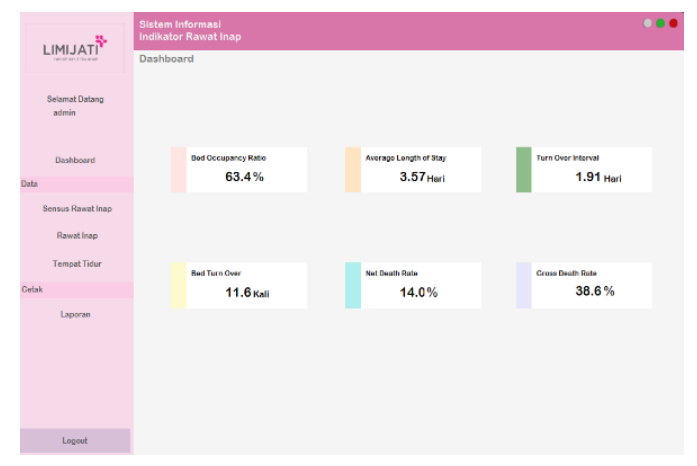

Gambar 7. Form Dashboard/Menu Utama

Setelah masuk di laman login pada aplikasi, akan muncul tampilan Dashboard atau laman menu utama. Pada bagian ini terdapat beberapa menu yang dapat kita kunjungi atau kita pilih sebagai pengolah pelaporan rekam medis berbasis komputer ini . Dibagian kiri terdapat beberapa menu seperti sensus rawat inap, rawat inap, tempat tidur dan cetak pelaporan. Selain itu ditampilan depan terdapat beberapa menu lainnya untuk melihat data seperti Bed Occupancy Ratio, Average Length of Stay, Turn Over Interval, Bed Turn Over, Net Death Rate dan Gross Death Rate. Dimenu dashboard pun kita sudah bisa melihat data seperti hasil keseluruhan dari tiap menu.

\section{Form Rawat Inap}

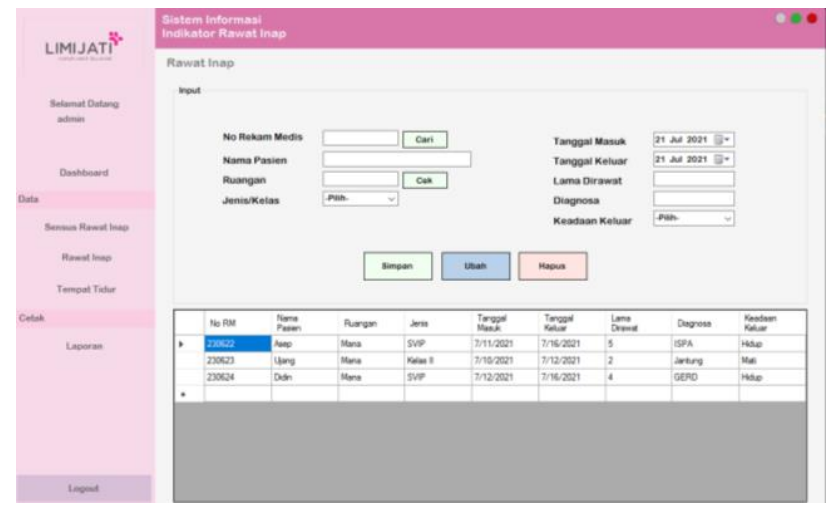

Gambar 8. Form Rawat Inap

Pada form rawat inap ini bisa digunakan untuk mencari data pasien yang sedang rawat inap. Dengan aplikasi ini bisa dengan mudah untuk menyimpan, mengubah atau menghapus data. Setiap pasien yang ada di ruang rawat inap akan diinput data nya menggunakan aplikasi ini. Data yang diinput meliputi nama pasien, nomor/nama ruangan, jenis/kelas, tanggal masuk, tanggal keluar, lama dirawat, diagnosa, dan keadaan keluar. Setelah semua data diinput kita bisa melihat data secara keseluruhan pada tabel yang disajikan dibawah pengisian data. Pengisian data seperti ini akan mempermudah kita untuk mencari informasi pasien terutama yang sedang rawat inap. 
Fajrina Aulya ${ }^{1}$, Irda Sari ${ }^{2}$

5. Form Ketersediaan Tempat Tidur

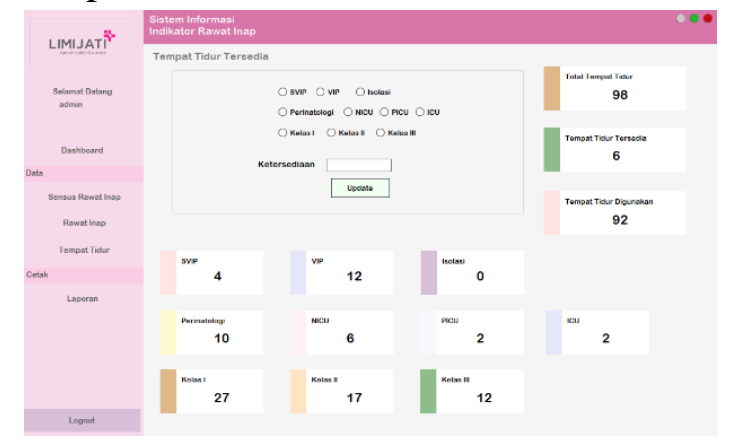

Gambar 9. Form Ketersediaan Tempat Tidur

Dalam situasi dan kondisi tertentu, informasi mengenai ketersediaan tempat tidur sangat diperlukan dengan cepat. Apalagi jika pasien dirumah sakit dengan membludak dan wabah penyakit semakin marak menyerang masyarakat, biasanya sebelum menerima pasien rawat inap akan dicek terlebih dahulu ketersediaan tempat tidurnya. Tempat tidur untuk pasien di Rumah Sakit Limijati dibagi ke dalam beberapa kategori yaitu SVIP, VIP, Isolasi, Perinatologi, NICU, PICU, ICU, Kelas I, Kelas II, dan Kelas III. Kita bisa melihat berapa banyak kasur yang telah digunakan di semua ruangan tersebut, selain itu pada menu form ketersediaan tempat tidur disajikan total keseluruhan tempat tidur, tempat tidur yang masih tersedia dan tempat tidur yang sudah digunakan.

\section{Form Sensus Harian}

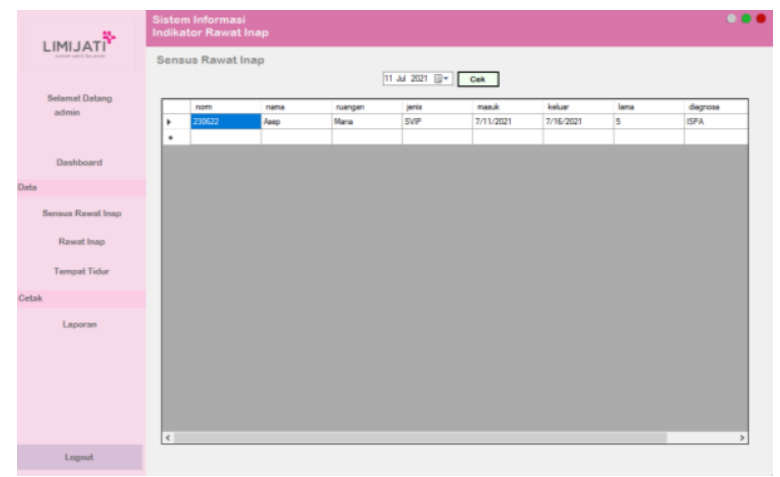

Gambar 10. Form Sensus Harian

Form sensus harian digunakan untuk mengeck keberadaan pasien disetiap harinya. Sensus harian dilakukan untuk memonitoring pasien sesuai data yang diinput pada di awal pengisian form rawat inap. Dalam rekapm medis, sensus inilah yang menjadi sumber perkembangan pasien saat rawat inap. Pengolahan data disensus ini harus dilakukan dengan teliti dan pwnuh hati-hati karena kita salah dalam menginput data maka data rekam medis pasien akan salah total. Dengan adanya aplikasi seperti ini kita bisa lebih mudah mengupdate data pasien dan menyimpan riwayat sakitnya selama berada dirumah sakit. 
7. Form Laporan Perkelas Perawatan

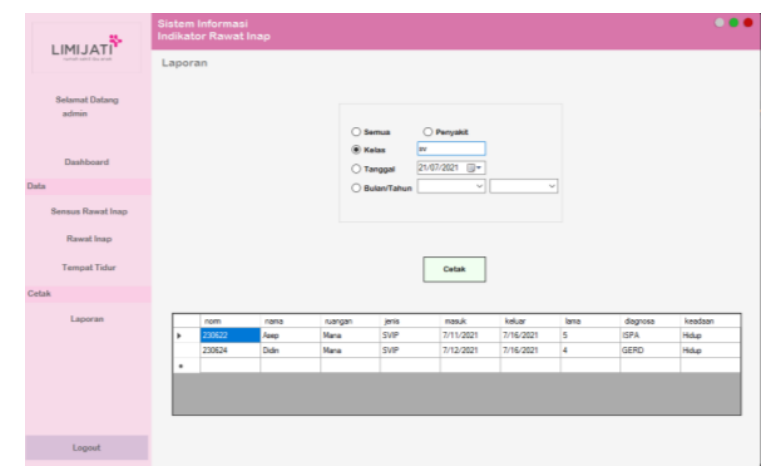

Gambar 11. Form Laporan Perkelas Perawatan

Dalam sistem administrasi, proses pelaporan harus dilakukan dengan data yang valid sesuai situasi dan kondisi pasien. Semua data yang diinput bisa dengan mudah kita dapatkan dan siap cetak. Pada form ini disediakan untuk cetak laporan sesuai dengan perkelas perawatan. Proses pencarian data sesuai kategori pada kelas perawatan dibutuhkan saat ingin mengecek data pasien sesuai dengan kelas perawatannya agar lebih terdeteksi nama pasien disetiap ruangannya.

\section{Form Laporan Per-tanggal}

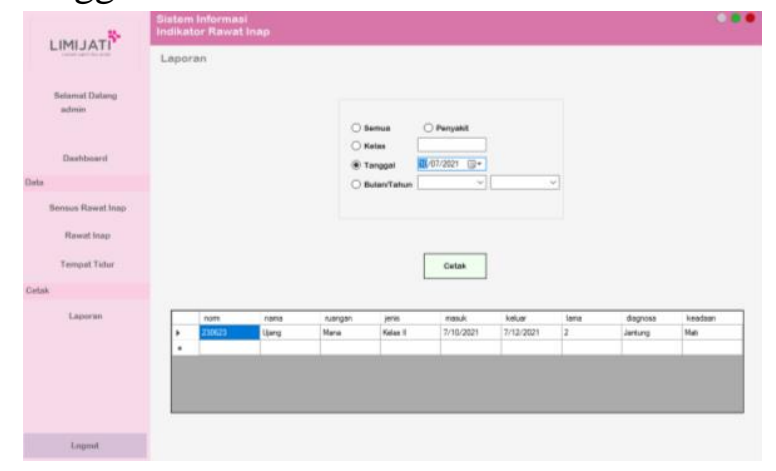

Gambar 12. Form Laporan Per-Tanggal

Form ini menyediakan informasi untk melihat data sesuai tanggal saja. Kita bisa melihat siapa saja pasien yang masuk dan keluar di rumah sakit. Cara untuk mendapatkan informasi tersebut cukup dengan memasukkan tanggal yang akan kita cari datanya kemudian secara otomatis akan muncul tabel data yang menyediakan informasi pasien sesuai data yang diinput. Pencarian sesuai kategori data ini akan lebih mempermudah dalam pencarian data pasien. 
Fajrina Aulya ${ }^{1}$, Irda Sari ${ }^{2}$

9. Form Laporan per-bulan

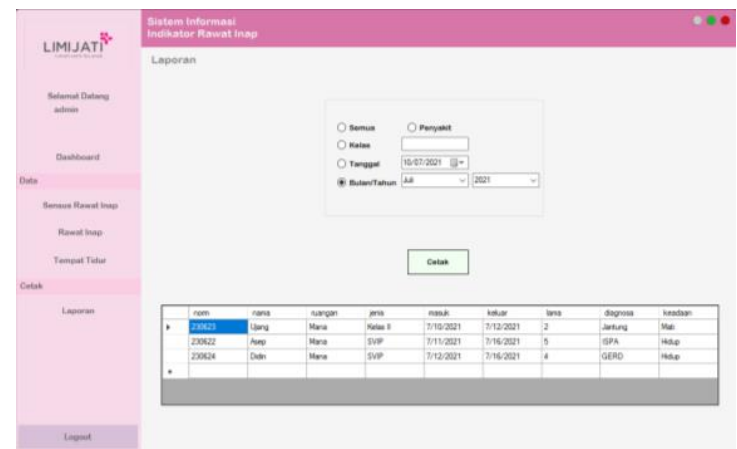

Gambar 13. Form Laporan Per-bulan

Selain bisa mencari informasi pertanggal, pencarian data pasien perbulan pun bisa didapatkan pada aplikasi ini. Pencarian data per-tiap bulan ini sangat diperlukan untuk mengecek pasien disetiap bulannya. Selain kita bisa melihat data secara langsung, kita juga mencetak file nya sebagai kebutuhan fisik administrasi dengan menekan tombol cetak. Informasi yang disampaikan pada aplikasi ini bersifad valid sesuai dengan dataan pasien selama di rumah sakit.

10. Form Laporan Keseluruhan

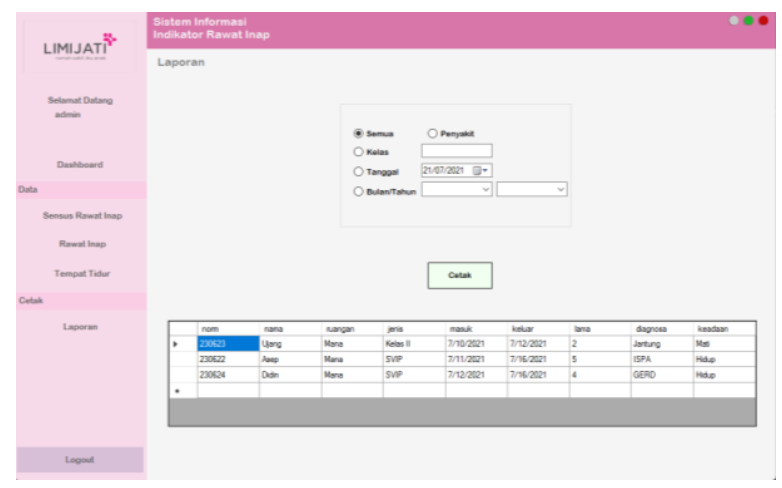

Gambar 14. Form Laporan Keseluruhan

Form laporan kesuluruhan mencakup semu informasi pada pasien. Informasi yang bisa didapatkan dari pelaporan perkelas perawatan meliputi nomor registrasi, nama, ruangan, jenis kelas, tanggal masuk, tanggal keluar, lama penginapan, diagnosa dan keadaan pasien. Biasanya laporan secara keseluruhan digunakan untuk melihat perkembangan rumah sakit dan arsip bagi dataan pasien yang berobat ke rumah sakit.

Secara keseluruhan pembuatan aplikasi ini memiliki banyak keuntungan dalam hal pelaporan secara komputerisasi atau sistem informasi yang baru, diantaranya :

a. Dalam mengolah data, petugas tidak banyak menggunakan rumus karena semua selah diatur oleh sistem.

b. Dapat menghemat waktu saat perekapan data dan pengisian data.

c. Segala sesuatu bentuk informasi dapat diperoleh dengan cepat. 


\section{Kesimpulan}

Berdasarkan penelitian yang dilakukan mengenai pembuatan sistem informasi indikator rawat inap menggunakan microsoft visual studio 2010 di rsia limijati memberikan banyak manfaat bagi seluruh tenaga medis maupun pasien. Proses penginputan data sudah bisa dilalukan secara komputerisasi menggunakan aplikasi ini. Hasilnya, data rekam medis pasien tersimpan dalam aplikasi yang jika kita membutuhkan data tersebut kita akan mudah mebdapatkannya karena banyak fitur-fitur menu yang disediakan dalam aplikasi. Dengan adanya inovasi pembuatan aplikasi pengolah data rekam medis, kita bisa lebih hemat dalam pengguaan kertas, mempercepat pelayanan rumah sakit dan memberikan informasi pelayanan yang valid. 
Fajrina Aulya ${ }^{1}$, Irda Sari ${ }^{2}$

\section{Bibliografi}

Giyana, Frenti. (2012). Analisis Sistem Pengelolaan Rekam Medis Rawat Inap Rumah Sakit Umum Daerah Kota Semarang. Jurnal Kesehatan Masyarakat, 1(2), 48-61.

Handiwidjojo, Wimmie. (2015). Sistem Informasi Manajemen Rumah Sakit. Jurnal Sistem Informasi, 2(1), 17.

Handiwidjojo, Wimmie. (2017). Rekam medis elektronik. Jurnal Informasi Kesehatan, 2(1), 38-42.

Kaban, Ita Ernala. (2012). Tata Kelola Teknologi Informasi - (IT Governance). Jurnal Ilmu Komunikasi Dan Informasi, 2(1), 1-5. https://doi.org/10.21512/commit.v3i1.505

Lestari, Endang, Tania, Ken Ditha, \& Rahmi, Lailatur. (2011). Sistem Informasi Rekam Medik Pada Rumah Sakit Bersalin Graha Rap Tanjung Balai Karimun. Palembang: Universitas Sriwijaya.

Perdana, Aji Bagus, Negara, Arif Bijaksana Putra, \& Irwansyah, M. Azhar. (2016). Rancang Bangun Sistem Informasi Rekam Medis Berbasis Website (Studi Kasus: Rumah Sakit Umum Daerah Sultan Syarif Mohamad Alkadrie). JUSTIN (Jurnal Sistem Dan Teknologi Informasi), 4(2), 289-294.

Priyadi, Didin Agus, \& Lestari, Endah Wiji. (2018). Perancangan Sistem Informasi Pelayanan Surat Menyurat Pada Kantor Desa Tanjungsari Kutowinangun Kebumen Berbasis Desktop. Jurnal Teknik Komputer, 4(2), 84-91. https://doi.org/10.31294/jtk.v4i2.3444

Putra, Chandra Anugrah. (2015). Pemanfaatan Teknologi Gadjet Sebagai Media Pembelajaran. Universitas Muhammadiyah Palangkaraya, 3(2), 14. https://doi.org/10.33084/bitnet.v2i2.752

Rustiyanto, Ery. (2010). Sistem informasi manajemen rumah sakit yang terintegrasi. Yogyakarta: Gosyen Publishing, 6(7), 31.

Sudarmilah, Endah, Supardi, Agus, \& Muliawan, Edo Ananda. (2017). Aplikasi Administrasi Laboratorium Pada Rumah Sakit PKU Muhammadiyah Delanggu. Jurnal Emotor, 12(01), 8-15.

Susanto, Gunawan, \& Sukadi. (2011). Sistem Informasi Rekam Medis Pada Rumah Sakit Umum Daerah ( RSUD ) Pacitan Berbasis Web Base. Jurnal Speed - Sentra Penelitian Engineering Dan Edukasi, 3(4), 18-24. http://dx.doi.org/10.3112/speed.v3j4.922

Tanjung, Irwandi, \& Sukrianto, Darmanta. (2017). Perancangan Sistem Informasi Rekam Medis Terpadu Dalam Upaya Meningkatkan Pelayanan Rumah Sakit Jiwa Tampan Prov. Riau. Jurnal Intra-Tech, 1(1), 43-54. 
Perancangan Sistem Informasi Indikator Rawat Inap Menggunakan Microsoft Visual Studio di RSIA Limijati

Winati, \& Supriyanto, Stefanu. (2013). Analisis Kelengkapan Pengisian dan Pengemblin Rekam Medis Rawat Inap Rumah Sakit. Jurnal Administrasi Kesehatan Indonesia, 1(4), 345-351. 